\title{
Introduction to the Special Issue on "Exchange Rates, Financial Integration and Uncertainty"
}

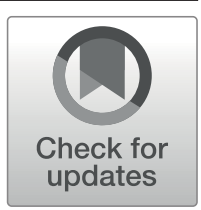

\author{
Ansgar Belke 1,2,3,4
}

Published online: 24 April 2020

(C) The Author(s) 2020

From June 21 to 24, 2018, the European Economics and Finance Society (EEFS) hosted its seventeenth Annual Conference in London in close collaboration with the journal "Open Economies Review". This special issue presents a peer-reviewed selection of the papers on the topic "Exchange Rates, Financial Integration and Uncertainty" "presented at the conference.

The special issue starts with an invited paper on "The Euro Crisis in the Mirror of the EMS: How Tying Odysseus to the Mast Avoided the Sirens but Led Him to Charybdis" by Barry Eichengreen, Giancarlo Corsetti, Galina Hale and Eric Talllman. They ask why recovery from the Euro Area crisis was in the end delayed for a decade. Their explanation lies in the absence of credible and timely policies to backstop financial intermediaries and sovereign debt markets. In their paper they add substance to this analysis, contrasting recent experience with the 1992-93 crisis in the European Monetary System, when national central banks and treasuries more successfully provided this backstop. They argue that the incomplete development of the Euro Area constrained the ability of the ECB and other European institutions to do likewise in the more recent episode.

The first cluster of papers deals with monetary union issues, again with a specific focus on Europe.

The first, more general, paper in this cluster by Paolo Canofari, Marcello Messori and Alessandra Marcelletti focuses upon "Redenomination Risk and Bank Runs in a Monetary Union With and Without Deposit Schemes". The authors develop a basic framework characterized by a monetary union in which a shock to the policy interest rate, i.e. the determinant of a recessionary stance in the monetary policy, can imply that a member state finds it worthwhile to leave this union and/or that the corresponding

Ansgar Belke

ansgar.belke@uni-due.de

1 University of Duisburg-Essen, Essen, Germany

2 Centre for European Policy Studies, Brussels, Belgium

3 King's College, London, UK

4 Institute for the Study of Labor, Bonn, Germany 
banks declare bankruptcy. Their aim is to analyze the various possible reactions that bank depositors may have when this shock is transmitted to the interest rates on their bank deposits. They compare these reactions in two different policy frameworks characterized either by the presence or by the absence of a Centralized Deposit Insurance Scheme (CDIS). Their model shows that the introduction of a CDIS is per se not sufficient for zeroing the probability of bank runs.

As the second entry Pavel Gertler, Roman Horváth and Júlia Jonášová present their paper on "Central Bank Communication and Financial Market Comovements in the Euro Area". They examine whether the unscheduled communication of members of the European Central Bank's (ECB) Governing Council affects financial market comovements. To assess comovements, they employ well-defined measures of stock market and government bond yield coexceedances, i.e., the measures of whether markets jointly decrease or increase and by how much. They use daily data from 2008 to 2014 for the four largest Euro area countries, i.e. Germany, France, Italy and Spain, in a quantile regression framework and control for persistence in coexceedances and a comprehensive set of relevant factors capturing returns and volatility in various segments of financial markets. The authors find that central bank communication often contributes to greater coexceedances but only when there are extreme events in the financial markets. The results also suggest that markets perceive the ECB's communication as a euro area-wide shock, but the propagation of this shock depends on the financial (in)stability of individual Euro area countries.

The third paper in this row is "The Sustainability of External Imbalances in the European Periphery" by Vassilis Monasteriotis and Cigdem Borke Tunali. They start from the insight that the issue of external imbalances has become a key concern in the global economy, gaining particular prominence also inside Europe, following the Eurozone crisis. Comparatively, however, evidence for the European periphery is much less developed. In their study, the authors investigate the sustainability of external imbalances in 15 countries from the EU's so-called eastern and superperiphery across a range of sustainability tests. They find that external imbalances are, on the whole, large and, despite some significant adjustments in the post-crisis period, they continue to follow paths that are possibly unsustainable. Their results show a higher likelihood of confirming sustainability when looking separately at the current account and the net foreign asset position than when looking jointly at the current and capital accounts (and thus at the intertemporal budget constraint - Bohn, 2007). This suggests, albeit tentatively, problems and vulnerabilities that go beyond simple concerns about price competitiveness and the trade performance of the countries under study.

The next category of papers is related to international spillovers.

"Net Foreign Asset Positions, Capital Flows and GDP Spillovers" by Joscha Beckmann and Robert Czudaj is the first paper in this regard. The authors shed light on global GDP spillovers in the context of external imbalances. For this purpose, they adopt a Bayesian time-varying panel vector autoregression framework to analyze the global implications of changes in assets and liabilities of the US and the Euro Area in a global framework which includes 25 industrial and emerging economies. They find significant evidence for assets and liabilities spillovers from positions in the Euro Area and the US which often result in negative effects on GDP growth. 
The second paper dealing with international spillover issues is "Financial Integration in the GCC Region: Market Size versus National Effects" authored by Kerim Peren Arin, Guglielmo M. Caporale, Kyriacos Kyriacou and Nicola Spagnolo. This paper examines financial spillovers between the four largest equity markets (by market capitalization) in the GCC region using a VAR-GARCH framework that sheds light on interdependence as well as the effects of the 2014 oil crisis. Since the UAE is a federation including two stock exchanges (Abu Dhabi and Dubai), it is possible to test whether being part of a federal union matters more than market size in terms of financial integration. Their results suggest that the latter is more important, since we could not find evidence of stronger linkages between the Abu Dhabi and Dubai markets compared to those between other markets in the region. By contrast, there are significant spillover effects, both in the mean and in the volatility, from the largest market of Saudi Arabia to Qatar and the two markets in the UAE, which confirms that market capitalization is a more important determinant of financial integration than belonging to a federal union. Further, spillovers from the larger markets have become stronger as a result of the 2014 oil crisis. Finally, there is also evidence of spillovers from the smaller to the larger markets.

The next paper by Christopher Thiem looks at "Cross-category, Trans-pacific Spillovers of Policy Uncertainty and Financial Market Volatility". It thus mixes spillover issues with uncertainty aspects. Using generalised variance decompositions from vector autoregressions, he analyses cross-country, cross-category spillovers of economic policy uncertainty (EPU) and financial market volatility between the US and Japan. His model includes indices of monetary, fiscal and trade policy uncertainty for each country, as well as three measures of option-implied stock market and exchange rate volatility, respectively. He finds that the financial market volatility indices are usually substantial net spillover transmitters towards the total group of EPU measures. However, the Japanese equity and especially the FX volatility index are typically more affected by EPU spillovers than the US VXO. His results also reveal that, compared to within-country spillovers, cross-country spillovers of EPU are relatively small and less volatile. Finally, he shows that the direction of net EPU spillovers between the US and Japan is both time- and category-dependent with different EPU categories acting as strong sources of uncertainty spillovers throughout the sample period.

The paper by Camelia Turcu, Monica I. Pop Silaghi and Valentina-Ioana Mera titled "Economic Uncertainty and Money Demand Stability in CEE Countries" also deals with uncertainty issues. The authors identify a money demand function that takes account of the heterogeneities of the Central and Eastern European Countries (CEECs) in the context of the European integration. They extend the traditional specification of money demand to capture the effect of a change in agents' expectations regarding the dynamics of economic activity. The traditional determinants of the demand for money (real GDP, interest rate, inflation rate) are found to be significant and have the expected sign. Above this, the authors also find that the role of economic sentiments - captured through the European sentiment indicator (ESI) - is significant in explaining the money demand: consumers' and investors' gloomy expectations concerning future economic developments lead to an increase in domestic money demand, due to precautionary reasons. Their results also suggest that a currency substitution effect, against both euro and USD, is present in the CEECs.

Three papers on exchange rates follow. 
The first contribution is "The Yen Exchange Rate and the Hollowing-out of the Japanese Industry" by Ansgar Belke and Ulrich Volz. They start with the observation that the Yen has seen several episodes of strong appreciation since the demise of the Bretton Woods system. These appreciations have not only been associated with "expensive Yen recessions" resulting from negative effects on exports; since the late 1980 s, the strong Yen has also raised concerns about a de-industrialisation of the Japanese economy. Against this backdrop, the authors investigate the effects of changes to the Yen exchange rate on the hollowing out of the Japanese industrial sector. To this end, the paper uses both aggregate and industry-specific data to gauge the effects of Yen fluctuations on the output and exports of different Japanese industries, exploiting new data for industry-specific real effective exchange rates. The authors' findings support the view that the periods of yen appreciation had more than just transitory effects on Japanese manufacturing. The results also provide indication of hysteresis effects on manufacturing. While there are also other factors that have contributed to a hollowing out of Japanese industry, a strong Yen played a role, too.

The second paper by Ahmad H. Ahmad and Eric J. Pentecost bears the title "Testing the 'Fear of Floating' Hypothesis: A Statistical Analysis for Eight African Countries". It revisits the fear of floating hypotheses for eight African countries from the collapse of the Bretton Woods fixed exchange rate system in the early 1970s up until December 2017. This long period of calendar time allows the authors to extend previous studies by examining the fear of floating hypotheses in two distinct ways. First, they look at a set of descriptive statistics to compare the degree of exchange rate flexibility under alternative de jure exchange rate regimes. They do not find any statistical difference between exchange volatility between declared floaters and fixers, but greater reserve volatility between the floaters, which is suggestive of fear of floating. Second, the authors use a non-linear, threshold VAR model, estimated for each country, to test for a relationship between exchange rate changes and reserve changes. The results suggest some evidence of a fear of floating for countries which have declared a de jure floating regime, with the regime-dependent impulse responses indicating that exchange rate appreciation due to positive reserve shocks is more prevalent in the high reserve regimes, indicative that level of foreign reserves available are important for their exchange rate policies. In general, although the countries with de jure floating regimes have a lower threshold than those with pegged regimes, reserves adjust by more than the exchange rates showing a fear of floating.

The third paper which deals with exchange rates is "Extreme Bounds Analysis in Early Warning Systems for Currency Crises" by Tjeerd M. Boonman and Andrea E. Sanchez Urbina. They argue that selecting early warning indicators to predict currency crises is not straightforward, because there are several mechanisms that lead up to currency crises and these mechanisms change over time and are not always visible, obvious or linear in nature. Traditionally, early warning indicators are selected from theory, stylized facts or meta-studies. The alternative is to use data-driven processes. In this regard, the authors propose the Extreme Bounds Analysis (EBA), which can handle unbalanced panels better than other methods and can be used in a logit model. They use the selection of indicators determined by the EBA in an Early Warning System and compare the performance with a benchmark EWS, where the indicators are chosen from a meta-study of the literature. They find for a sample of 33 emerging economies that the determinants of currency crises confirm a large number of the early 
warning indicators from the literature, but also exhibit differences, which provide more insight in crisis mechanisms. Applying the determinants in an Early Warning System, the authors find that the EBA-selection outperforms the benchmark in the in-sample period (1990\{2010). In the out-of-sample period (2011\{2018) the EBA-selection performs better in the majority of the specifications.

The special issue concludes with the contribution "Is Private Debt Excessive?" by Jean-Charles Bricongne, Leonor Coutinho, Alessandro Turrini and Stefan Zeugner. The authors start from the stylized fact that private debt stocks have increased significantly around the world. As a by-product, several countries have accumulated large negative net international investment positions, while the debt overhang threatens potential growth. High debt also creates additional difficulties for policymakers, by affecting the channels of monetary policy transmission. Gauging the extent to which private debt is excessive helps to understand the risks to global financial stability and the policy challenges going forward. Accordingly, the authors propose methodologies to benchmark the debt of non-financial corporations and households by comparing debt-to-GDP ratios to a threshold beyond which the probability of a banking crisis becomes relatively high (prudential benchmark), borrowing from the literature on early-warnings, and to the level of debt that can be justified by economic fundamentals (fundamentals-based benchmark). The latter are computed on the basis of an empirical econometric analysis of the determinants of debt accumulation. Both benchmarks can be used together in macroeconomic surveillance to assess debt from complementary perspectives.

The European Economics and Finance Society's (EEFS) seventeenth Annual Conference in London provided the great opportunity for participants to gain new insights into a couple of highly topical issues related, above all but not exclusively, to exchange rates, financial integration and uncertainty. I am grateful to George Tavlas for granting us space for a special issue of the Open Economies Review. I am also heavily indebted to the referees of the papers included in this special issue. Their reports resulted in substantial and significant improvements that have been highly appreciated by the authors of papers accepted in this special issue.

Funding Information Open Access funding provided by Projekt DEAL.

Open Access This article is licensed under a Creative Commons Attribution 4.0 International License, which permits use, sharing, adaptation, distribution and reproduction in any medium or format, as long as you give appropriate credit to the original author(s) and the source, provide a link to the Creative Commons licence, and indicate if changes were made. The images or other third party material in this article are included in the article's Creative Commons licence, unless indicated otherwise in a credit line to the material. If material is not included in the article's Creative Commons licence and your intended use is not permitted by statutory regulation or exceeds the permitted use, you will need to obtain permission directly from the copyright holder. To view a copy of this licence, visit http://creativecommons.org/licenses/by/4.0/. 